\title{
Study Learning Style for Early Childhood Age
}

\author{
Dra. Hj. Izzati M.Pd
}

\begin{abstract}
Learning in early childhood is a process of interaction between children, parents, or other adults in an environment to achieve its goals. Interaction is built it is a forward factor to achieve the learning objectives to be achieved. This raises the interaction with a relationship where the child will produce meaningful experience, high mental activity in the child will produce meaningful experience, high mental activity in the child can be formed through interaction with others. The task that has been done by the teacher, the child still has the opportunity to make a choice decision material and materials. Throughout the day the teacher acts as a partner who likes to be interested in what the child is doing. Master is important, listening, interacting, encouraging children, helping to solve problems. In case of conflict, the teacher is not sertamerta siding. Teachers model the correct behavior and relate it to the child's experience. The involvement of the child to be responsible for the solution or the result itself. Creating a supportive atmosphere supports the needs of the child. Children learn actively, they focus on interest, and evaluate them, try ideas, talk about what they do, solve their own problems.
\end{abstract}

Keywords : learning, early childhood, experience.

\section{UNDERSTANDING LEARNING IN EARLY CHILDREN AGE}

Early childhood learning is a process of interaction between children, parents, or other adults in an environment to achieve its developmental tasks. The built interaction is a developmental task. Interaction is built is a factor that affects the achievement of learning objectives to be achieved. This is because the interaction reflects a relationship where the child has a meaningful experience, so that the learning process can take place smoothly. According to Vigotsky (Berk, 1994) argues that the child's thought process experience. High mental activity in children can be formed through interaction with others.

Learning will be a meaningful experience for the child if he can do something about his environment. In this case it can be said that learning is an opportunity for children to create and manipulate objects or ideas. Breenberg (1994) argues that the child will be involved in learning more intensively if he builds something rather than merely performing or imitating something built by others. He illustrates that learning can be effective if children can learn through work, play and live together with their environment.

In essence children learn while playing, therefore learning in early childhood is basically playing. In accordance with the characteristics of early childhood that is active in conducting various explorations of the environment, then the play activities are part of the learning process. Learning is directed at the development and improvement of the potential of abilities such as language skills, socioemotional, motor, and intellectual. For that learning at this age should be designed so that children do not feel burdened in achieving development tasks. In order for the learning environment not to burden and bore the child, the learning atmosphere needs to be made naturally, warm, and fun. Playful activity that gives children the opportunity to interact with their friends and the environment is paramount. In addition, because the child is a unique individual and very varied, then the elements of variations and interests of children also need to be considered.

In connection with the achievement of developmental tasks in the learning process mentioned above, then some things to note include: (1) children feel psychologically secure and their physical needs are met; (2) children can construct 
knowledge; (3) children learn through social interaction with adults and other children; (4) a child's learning activity reflects an unbroken circle that starts with consciousness then turns to export, search and ultimately to use; (5) children learn through play; (6) interests and needs of children to know are met; And (7) the individual variations of the child are noticed (Bredekamp and Rosegrant: 1992 quoted from Solehudin: 2002).

\section{LEARNING PRINCIPLES IN EARLY CHILDREN AGE}

\subsection{Departing from the Child}

Each child brings all the knowledge he has had on his new experiences. If a learning experience does not give children the opportunity to create new knowledge, then that learning will be boring. Conversely, if the learning experience is too foreign to the child, then the experience will make children anxious. This will cause the child to withdraw or refuse to relate to the new experience. Thus, the learning experience should contain some of the elements already known by the child and others are new experiences. In these situations the child may be interested in interacting with his or her new experience and have the opportunity to manipulate or express something (Schickedanz, et al, 1990).

\subsection{Learning Must Challenge Child Understanding}

The process of learning in early childhood can occur in two directions: from the general to the particular from the simple to the complex. Therefore, to ensure the development of the child, the designed learning activity must challenge the child to develop an understanding according to what he experienced. When the child has been able to complete the first challenge, then the child should be given the next challenge is more difficult than the first. For example, when the child has been able to arrange a game of a beam, then the child's next game should be given more and varied amounts in shape and size. This will evoke a sense of challenge in the child to be able to complete the next game. If the child is not stimulated by the next game, then in addition to children will be bored also the child's understanding will not develop optimally.

\subsection{Learning is Done While Playing}

Learning in early childhood is playing. Through play can provide opportunities for children to explore, discover, express feelings, create, and learn fun. In addition, playing can also help a child know about himself, with whom he lives, and in which environment he lives. Some play principles that can meet the study criteria include the following:

1) Play is a learning tool

2) Play comes from within the child

3) Play free and free from binding rules

4) Play is real or real activity

5) Play more focused on process than result

6) Play should be dominated by players

7) Play must involve the active role of the player

In order to play can be obtained optimal learning results, then the meaning can be done by parents, teachers and other adults. Children should not be allowed to play alone, because it can reduce the meaning of learning contained in the play.

\subsection{Using Nature as a Learning Facility}

Nature is an infinite means for children to explore and interact in building their knowledge. As developed by Robin Dranath Tagore is one of the learning models where almost $90 \%$ of activities are done by interacting with nature. In this learning the child is taught to be able to build an emotional bond between his friends. What can be done in this lesson is to create learning pleasure, build relationships and affect the memory and memory long enough for the materials that have been studied (Bobby the Potter: 2000).

Phillipe Vaquette (2001) suggests that there are three important aspects in nature:

1) Nature is the scope for rediscovering identity collectively and recasting social life.

2) Nature is a scope that can be explored. If children are unfamiliar with the location of the activity, the child will spend most of the time available to find out what they are likely to do there.

3) The role of educators in the location of activities. An educator must be both a teacher, educator, and advisors activities. A good teacher should be able to provide knowledge that can be applied by the students.

\subsection{Learn to be done through the sensor}

Children acquire knowledge through sensory or sensory ie touch, smell, listener, vision, and taste. Each child's sensory will respond to 
stimuli or stimuli received. Therefore learning should provide stimulation that can stimulate every sensory that children have. Various forms of stimulant that can be given as for children aged 3 years can be given a puzzle toy that will stimulate sensors touch and vision of children, so as to develop the cognitive abilities of children. Such stimulation activities can provide a direct experience to the child to manipulate objects. To that end, educators and parents and adults can create a variety of directed stimulation program designs that can be performed by the child through his or her sensual experiences.

\subsection{Learning to Equip Life Skills}

Learning essentially equips children to have life skills. Likewise with early childhood that the learning we provide must equip the child to have life skills in a very simple sense according to the ability of the child. For example, children can wear their own shoes, combing their hair, eating and drinking themselves. Responsible for himself.

\subsection{Learn While Doing}

Education should lead children to become active learners. Creatively designed education will produce an active learner. Children will be accustomed to learning and learning various aspects of knowledge, attitudes and skills, discussing, summarizing and expressing themselves about the things found in their environment. The process of education like this is a form of learning that relies on active learning activities of children (active learning).

Student Activity Learning is a form of learning inspired by John Dewey (learning by doing) and forwarded by Killpatrik with project teaching. Project teaching is basically a child is required to be able to solve various problems faced by the child. Project learning gives children the opportunity to be active, willing to work and productively find new knowledge.

As a teacher to carry out learning activities should be able to refer to various principles of early childhood learning above, so that learning can run effectively and efficiently to achieve growth and development of children optimally.

Understanding of early childhood learning by playing, is now expected to be better understood by the managers, educators or observers. Even if it has not been implemented at least have started or would open the heart to deepen how the framework of early childhood learning program. Disi is required by the teacher to be able to design the right strategy so the classroom can be the "home" where the child is open to feedback, but also the place to find them learning to acknowledge and support others, where they experience joy, give and receive, learn and grow. This is what is termed as the context of organizing the learning stage. Therefore, teachers are required to apply an appropriate strategy in learning to enable the achievement of better learning effectiveness. Conversely, learning will be a problem for children, if children feel learning into something boring activity. It is therefore important for teachers to devise a strategy that can make learning fun. A fun learning strategy is a teacher's effort to create a fun atmosphere in learning, so that learning becomes more effective.

\section{SOME LEARNING APPROACHES}

Therefore, teachers should be able to use various learning approaches in early childhood so that learning is fun for children. There are three approaches that teachers can use in the learning process:

\subsection{Laissez-Fair Learning Atmosphere}

This strategy is very beneficial to children who have the power to be independent. An independent child shows his leadership, not too dependent on the teacher. If necessary, children come to the teacher. Creativity can flourish. He was not awkward either. Conversely for children who are less independent, requires a structured strategy. When less structured learning and free play are not restricted, children feel frustrated, do not know what to do, despair, anxiety, boredom, confusion, uncontrollability.

The positive aspect of this strategy mood, except for children who are self-sufficient, is the need to play a child is sufficient, play activities are valued and considered a reflection of real life.

\subsection{Guided Learning Environment}

In this learning style, activities are controlled by the teacher. The teacher talks, the child listens, follows the teacher's example and commands, drills and exercises according to the teacher's plan. Children who can not catch the example, are separated and corrected by the teacher. The child feels successful if he can do what the teacher wants. The learning atmosphere is colored by the many behaviors that teachers justify so that 
many children need constant teacher warning to complete their tasks.

\subsection{Strategy with a Supportive Atmosphere (Supportive Climate)}

Teachers and children share learning and experience. Teachers try to balance effectively between the active freedom of exploration and limiting in order to feel safe while studying. The teacher creates a learning environment with full of interest choices. Regularity in routine. Children are empowered to express themselves and carry out their activities.

Although the task has been planned by the teacher, the child still has the opportunity to make informed choices about materials and materials. Throughout the day the teacher acts as a partner who is interested in what the child does. Teachers observe, listen, interact, encourage children, help solve problems. In case of conflict, the teacher is not sertamerta siding. Teachers model the correct behavior and relate it to the child's experience. The involvement of the child to be responsible for the solution or the result of the problem solving itself. Create an atmosphere that supports supportive needs of children. Children learn actively, they focus on their interests, and their initiative, try ideas, talk about what they do, solve their own problems.

This method stimulates, strengthens the child's development in self-confidence, authentic in the work, initiative, and empathy. In the implementation of early childhood education, there is a lot of combination between laissez-fair learning atmosphere and guided / guided. Implementation of early childhood learning also requires an understanding of educators or managers about how children learn. Some concepts of how children learn are:

1. When he uses the senses

2. If there is any use of language for communication

3. When positive self concept

4. If there is an opportunity to explore

5. Find your own

6. When playing with friends

7. If the child is able to assess his or her own work

8. The child has a learning style

9. When he feels success

10. When the opportunity to play and interact with people with higher language
In the implementation of learning also paid attention to the child's own development. When learning without the burden of the child will advance rapidly. Early childhood competence can not be fully set. In terms of this competence it is better to see it with the continuum. So it is known the lowest and highest mastery, even a very complex.

Therefore the principle of learning in early childhood is through play activities. For children to play is a serious, but exciting activity. Through the katifitas play various work is realized. Playing is an activity chosen by the child for fun not because it will gain a prize or praise. Playing is one of the main tools that become an exercise for its growth. Playing is a medium in which the child tries himself not only in his fantasy but is also actively active. If the child is playing freely according to his will or at his own pace then he trains his abilities.

The game is a game for the child to explore his world from what he does not recognize to what is known, and from what he can not do to it. So playing has an important value for development in everyday life. By understanding the meaning of play for the child is a necessity for the child. For that teachers are expected to design a certain learning to do while playing, then learn in accordance with the demands of its development stage. If the need is not met there is a stage of development that functions less well and this will not look real immediately, but later when he was a teenager. While those whose needs are fulfilled are increasingly grown by having higher mental skills, to explore the world further and become a man who has the mental freedom to grow up according to his potential, to be a dignified and independent human more than that he is trained to continue Improve self-progress.

\section{IMPLEMENTATION}

In implementing appropriate learning styles educators need to master the various principles of learning for early childhood as well as applying various learning strategies or mastering various other approaches. For example, the knowledge of the holistic approach, the technique of involving the child in determining the learning, positioning the educator as the facilitator, the priority of the authentic work of the children themselves and the absence of necessity of a particular sequence or way of thinking linear. Various material preparations will be able to bring up various intelligence of children such as mathematical logic, language, music, sports, naturalist, visual and spatial, interpersonal and 
intrapersonal, moral and spiritual. Means processed activities to be absolutely necessary to think and develop. For this activity can be moved from the game media then developed into enrichment. Back here we are reminded that every game media can serve to develop physical factors, social emotions, and intelligence of children. In the routine with the movement rangasang brain and a variety of artwork and body work, to balance occurs. Of the various approaches that have been mastered educators must pour in the lesson plan. Therefore, the learning style in early childhood should be able to use a fun strategy for the achievement of learning objectives and the development of various aspects of child development optimally.

The role of educators in carrying out learning activities is to provide and enrich the learning experience of children. The way that can be done is to provide opportunities for children to perform various activities by exploring the environment and conduct interaction that is active sesame adults and the environment. Duni child is a world of play, play on children can be labeled as working in adults. Through children's play activities will acquire various abilities and skills. Playgrounds are done in their environment using means, game tools and utilizing various learning resources. Through fun play activities the child seeks to investigate and gain rich experiences, both with his or her own world, others and the environment.

\section{REFERENCES}

[1] Darmansah,(2010). Strategi Pembelajaran Menyenangkan Dengan Humor. Jakarta. Bina Aksara.

[2] Education indicators: An International Perspective; Juni 2002 (internet).

[3] Hartati Sofia,(2005). Perkembangan Belajar Pada Anak Usia Dini. Jakarta.

[4] Masitoh,Ocih,Heny,(2003). Pendekatan Belajar Aktif di Taman Kanak-Kanak. Jakarta. Depdiknas.

[5] Pusat Kurikulum(2002),Kompetensi dasar anak usia dini 4-6 tahun. Depdiknas Jakarta.

[6] Salehuddin M,(2000). Konsep Dasar Pendidikan Prasekolah. Bandung. UPI. 